\title{
REGULAR ARTICLE \\ INFLUENCE OF WATER SOLUBLE FERTILIZERS ON GROWTH IN BRINJAL HYBRID (SOLANUM MELONGENA L.)
}

\section{A. ANBURANI}

Department of Horticulture, Faculty of Agriculture, Annamalai University, Annamalai Nagar 608002, Tamil Nadu \begin{abstract}
In the present study, a field investigation was carried out to study the effect of water soluble fertilizers on growth and yield parameters of brinjal hybrids due to application of various levels of water soluble fertilizer. Foliar spray of NPK with 5 and 7 sprays, each starting from 30 DAT at $10 \mathrm{~d}$ interval, formed twenty treatments in two hybrids. The results showed that among the two different concentrations of foliar applied nutrients, 7 sprays of $1 \%$ NPK (19:19:19) along with 100 per cent recommended dose of fertilizer (200:150:100 $\mathrm{kg} \mathrm{ha}^{-1}$ ) recorded the highest plant height, number of primary branches, secondary branches, stem girth, number of leaves per plant, leaf area.
\end{abstract}

Keywords: Brinjal, Water soluble fertilizer, Growth parameters

\section{INTRODUCTION}

Brinjal (Solanum melongena L.) is one of the principle crops of India and is widely grown throughout the year in various parts of the country. The brinjal hybrids are more responsive to fertilizers application. Usually, the fertilizers are applied as soil drenching in brinjal cultivation. But due to various factors, the fertilizer responses will be low in soil application. Therefore, foliar nutrition may be a better way to supplement the nutrients to the plant [1].

Hence, field investigation was carried out to study the effect of water soluble fertilizers on growth and yield parameters of brinjal hybrids.

\section{MATERIALS AND METHODS}

A field experiment was carried out at University Orchard, Department of Horticulture, Faculty of Agriculture, Annamalai University, Annamalai Nagar, Tamil Nadu. Two brinjal hybrids viz., Mahyco No.39 (Ravaiya) produced by Mahyco Seed Innovation P. Ltd Maharashtra and Indam Supriya produced by Indo-American Hybrid Seeds (India) P. Ltd Bengaluru were used in the present study. The experiment was laid out in Factorial Randomized Block Design and replicated thrice. The treatments consisted of application of two levels of inorganic fertilizer (100\% and 75\% Recommended Dose Fertilizer @ 200:150:100 kg NPK) along with the two concentrations of water soluble fertilizers viz., NPK (19:19:19) at $0.5 \%$ and $1 \%$ as in five and seven sprays. Seeds were sown in raised beds at a spacing of $5 \mathrm{~cm}$ across the beds and at a depth of $0.25 \mathrm{~cm}$. Thirty five days old healthy seedlings were transplanted in the main field. The seedlings were planted in a uniform spacing of $90 \mathrm{~cm} \mathrm{x} 60 \mathrm{~cm}$ in the plot and immediately after transplanting. Intercultural operations and harvesting were done as per the recommendation. The required quantity of manures and fertilizers were applied as per the treatment. The inorganic fertilizers were applied in the form of urea, superphosphate and murate of potash as per the treatments. $\mathrm{N}$ was applied in two split doses, first dose was given as a basal application and the remaining $\mathrm{N}$ was given thirty days after sowing. The full dose of phosphorus and potassium were applied as basal application at the time of transplanting. Foliar application of required quantity of 19:19:19 NPK were given in five and seven sprays starting from thirty days after transplanting at ten days intervals. The observations on various growth parameters viz., plant height, number of primary branches, secondary branches, stem girth, number of leaves per plant, leaf area.

\section{RESULTS}

The plant height was significantly influenced by the interaction effect of treatments $\times$ hybrids. The maximum plant height was observed in $\mathrm{T}_{10} \mathrm{H}_{2}$ (100\% RDF+WSF $1.0 \%+7$ Sprays) with the mean value of $117.04 \mathrm{~cm}$. The highest number of primary branches (6.96), number of secondary branches (8.83) and number of leaves per plant (49.24) were recorded the maximum in $\mathrm{T}_{10} \mathrm{H}_{1}$. The maximum stem girth was observed in $\mathrm{T}_{10} \mathrm{H}_{2}(4.84 \mathrm{~cm})$ which received $100 \%$ RDF combined with $1.0 \%$ WSF (7 Sprays) in Ravaiya. The highest leaf area $\left(90.98 . \mathrm{cm}^{2}\right)$ were recorded in the same treatment.

\section{Received 28 February 2018; Accepted o3 April 2018}

*Corresponding Author

\section{A. Anburani}

Department of Horticulture, Faculty of Agriculture, Annamalai University, Annamalai Nagar 608002, Tamil Nadu, India

Email: anbumohankarthi2007@rediffmail.com

( This article is open access and licensed under the terms of the Creative Commons Attribution License (http://creativecommons.org/licenses/by/4.o/) which permits unrestricted, use, distribution and reproduction in any medium, or format for any purpose, even commercially provided the work is properly cited. Attribution - You must give appropriate credit, provide a link to the license, and indicate if changes were made. 
Table 1: Influence of water soluble fertilizers on growth parameters in brinjal

\begin{tabular}{|c|c|c|c|c|c|c|}
\hline Treatments & $\begin{array}{l}\text { Plant height } \\
\text { (cm) }\end{array}$ & $\begin{array}{l}\text { Primary } \\
\text { branches }\end{array}$ & Secondarybranches & $\begin{array}{l}\text { Stem girth } \\
\text { (cm) }\end{array}$ & $\begin{array}{l}\text { Number of } \\
\text { leaves }\end{array}$ & $\begin{array}{l}\text { Leaf area } \\
\left(\mathrm{cm}^{2}\right)\end{array}$ \\
\hline $\mathrm{F}_{1} \mathrm{H}_{1}$ & 71.94 & 4.13 & 6.12 & 2.15 & 25.87 & 49.26 \\
\hline $\mathrm{F}_{2} \mathrm{H}_{1}$ & 75.24 & $5 \cdot 30$ & 7.03 & 3.17 & 27.84 & 53.31 \\
\hline $\mathrm{F}_{3} \mathrm{H}_{1}$ & 81.38 & $5 \cdot 52$ & 7.22 & 2.30 & 29.89 & 56.36 \\
\hline $\mathrm{F}_{4} \mathrm{H}_{1}$ & 95.24 & 5.59 & 7.59 & $3 \cdot 31$ & 32.09 & 60.41 \\
\hline $\mathrm{F}_{5} \mathrm{H}_{1}$ & 86.09 & 5.62 & 7.87 & 3.34 & 34.99 & 64.15 \\
\hline $\mathrm{F}_{6} \mathrm{H}_{1}$ & 100.38 & 5.81 & 8.13 & $3 \cdot 31$ & 37.24 & 71.32 \\
\hline $\mathrm{F}_{7} \mathrm{H}_{1}$ & 90.18 & $5 \cdot 95$ & 8.24 & 3.09 & 41.99 & 75.25 \\
\hline $\mathrm{F}_{8} \mathrm{H}_{1}$ & 99.33 & 6.03 & 8.31 & 3.36 & 44.14 & 79.31 \\
\hline $\mathrm{F}_{9} \mathrm{H}_{1}$ & 104.38 & 6.12 & 8.46 & $3 \cdot 35$ & 46.15 & 82.35 \\
\hline $\mathrm{F}_{10} \mathrm{H}_{1}$ & 109.46 & 6.96 & 8.83 & 3.53 & 49.24 & 86.41 \\
\hline $\mathrm{F}_{1} \mathrm{H}_{2}$ & 83.05 & $3 \cdot 34$ & 4.83 & 2.20 & 21.81 & 56.53 \\
\hline $\mathrm{F}_{2} \mathrm{H}_{2}$ & 88.20 & 3.67 & 5.12 & 2.80 & 22.86 & 60.58 \\
\hline $\mathrm{F}_{3} \mathrm{H}_{2}$ & 92.15 & 3.78 & $5 \cdot 76$ & $3 \cdot 39$ & $25 \cdot 91$ & 63.63 \\
\hline $\mathrm{F}_{4} \mathrm{H}_{2}$ & 104.54 & 3.80 & 5.86 & 3.52 & 27.93 & 67.68 \\
\hline $\mathrm{F}_{5} \mathrm{H}_{2}$ & 97.20 & 3.96 & 6.08 & 3.72 & 29.98 & 71.73 \\
\hline $\mathrm{F}_{6} \mathrm{H}_{2}$ & 108.82 & 4.12 & 6.40 & 4.06 & 32.04 & 74.78 \\
\hline $\mathrm{F}_{7} \mathrm{H}_{2}$ & 101.78 & 4.23 & 6.25 & $3 \cdot 39$ & 35.09 & 78.83 \\
\hline $\mathrm{F}_{8} \mathrm{H}_{2}$ & 103.40 & 4.38 & 6.71 & 3.73 & 37.14 & 82.88 \\
\hline $\mathrm{F}_{9} \mathrm{H}_{2}$ & 112.24 & 4.53 & 6.90 & $4 \cdot 32$ & 40.19 & 86.93 \\
\hline $\mathrm{F}_{10} \mathrm{H}_{2}$ & 117.04 & 5.02 & 7.19 & 4.84 & 44.29 & 90.98 \\
\hline S. Ed & 2.31 & 0.30 & 0.15 & 0.12 & 1.62 & 1.75 \\
\hline $\mathrm{CD}(\mathrm{P}=0.05)$ & 4.63 & 0.60 & 0.31 & 0.24 & 3.25 & 3.51 \\
\hline
\end{tabular}

\section{DISCUSSION}

The increase in plant height in the present study might be due to the increased cell division and elongation at higher levels of N. Similar findings were reported by [2] and [2] in brinjal. The increase in plant height due to water soluble fertilizers used as foliar spray contain all the three major nutrients and nitrogen played an important role in increasing the plant height in brinjal [3]. In general, plant height increased with the increased levels of fertilizers. Similar result was also observed in the present study where the plant height increased with the increased combined levels of inorganic fertilizers. This finding was also supported by the views of [4] in brinjal.

Moreover, the plants supplied with higher dose of inorganic fertilizers were taller than the plants which received lower levels of inorganic fertilizer. In the present study, the increase in height with increased higher level might be due to the fact that the nitrogen which is a constituent of chlorophyll increased the synthesis of chlorophyll and have resulted in enhanced photosynthesis which ultimately resulted in better growth of the plant. Similarly, the role of $\mathrm{P}$ and $\mathrm{K}$ on vegetative growth has been emphasized by [5]. Phosphorus is also involved in the energy transfer system in the plant tissues. Hence, it is obvious that a good supply of phosphorus would generally improve the growth.

In the present study application of various levels of inorganic and water soluble fertilizers and the hybrids significantly influenced the primary and secondary branches. Among the interaction effect between hybrids $\mathrm{x}$ treatments the more number of primary and secondary branches were recorded in $\mathrm{T}_{10} \mathrm{H}_{1}$ (6.96 and 8.83) which received (100\% $\mathrm{RDF}+\mathrm{WSF} 1.0 \%+7$ Sprays) and the least was recorded in $\mathrm{T}_{1} \mathrm{H}_{2}(3.34$ and 4.83$)$ which received $75 \%$ recommended dose of fertilizers. The increase in number of branches was due to higher levels of nutrients supplied through foliar application of water soluble fertilizer at early crop stage could have encouraged more number of auxiliary buds and ultimately resulted in more number of branches. Similar results of better branching with foliar application of nutrients and inorganic fertilizers were reported by [6] in brinjal, [7] in tomato and [8] in chilli.

In the present study, application of various levels of foliar application of water soluble fertilizer significantly influenced the stem girth $(4.84 \mathrm{~cm})$, number of leaves (49.24), leaf area (90.98 $\left.\mathrm{cm}^{2}\right)$ and chlorophyll content (39.41). The highest values of all leaf characters recorded in $\mathrm{T}_{10} \mathrm{H}_{2}$ which received (100\% RDF+WSF 1.0\%+7 Sprays) and the least was recorded in $75 \%$ recommended dose of fertilizers in $\mathrm{T}_{1} \mathrm{H}_{1}$. It might be attributed by the solubility and uniform distribution of nutrients from the granules might have increased the nutrient availability in the root zone [9]. The leaves are major site of photosynthesis and act as a major source for the sink. Generally, the leaf production is determined both by environment and nutrition. Among the nutrients, nitrogen plays an important role in leaf production, being a chief constituent of protein and protoplasm it might have enhanced the chlorophyll content of leaves and cell division, thus resulting in more number of leaves [10]. Similar results were obtained by foliar application of nutrients by [3] in brinjal and [11] in okra.

\section{CONCLUSION}

Based on the present investigation, among the water soluble fertilizers and inorganic fertilizers tested foliar application of 7 sprays of NPK (19:19:19) along with the 100\% application of inorganic fertilizer (200:150:100 kg NPK ha-1) recorded the highest growth parameters in brinjal.

\section{REFERENCES}

1. Karpagam, R., M. Kannan, S. Natarajan and K. Srinivasan, 2004. Studies on the efficacy of foliar feeding of water soluble fertilizers on growth 
parameters and yield of brinjal hybrid COBH.1. South Indian Hort., 52(1-6): 139-142.

2. Prabhu, M., D. Veeraragavathatham, K. Srinivasan, L. Pugalendhi and J. Rajangam. 2004. Studies on the uptake of nutrients by brinjal hybrid $\mathrm{COBH}-1$. South Indian Hort., 52(1-6): 122-127.

3. Jilani, M. S., M. F. Afzal, W. Kashif. 2008. Effect of different nitrogen levels on growth and yield of brinjal (Solanum melongena). J. Agri. Res., 46: 245-251.

4. Sat pal, M. S. Saimbl and S. S. bal. 2002. Effect of nitrogen and phosphorus levels on growth and yield of brinjal hybrids (solanum melongena l.) Veg. Sci., 29 : 90-91.

5. Sundaram, V. and V. Kanthaswamy. 2005. Response of okra to foliar feeding of water soluble fertilizers. Veg. Sci., 32 : 92-93.

6. Chaurasia, S. N. S., K. P. Singh and Mathura Rai. 2005. Effect of foliar application of water soluble fertilizers on growth, yield, and quality of tomato (Lycopersicon esculentum L.) Sri Lankan J. Agric. Sci., 42:66-70.
7. Premsekhar, M. and V. Rajashree. 2009. Performance of hybrid tomato as influenced by foliar feeding of water soluble fertilizers. Am.-Eurasian J. Sustain. Agric., $3: 33-36$.

8. Deepadevi, N. and A. Shanthi. 2009. Effect of foliar spray of water soluble fertilizer on growth and NPK uptake of chilli hybrid (Capsicum annum L.). The Asian J. of Hort., 8 : 222-225.

9. Krishna moorthy, V. and A. K. A. Noorjehan hanif. 2014. Effect of water soluble and conventional fertilizers on growth and yield of chillies. J. Krishi. Vigyan., 2: 28-30.

10. Barooah, S. and A. Z. Ahmed. 1983. Effect of NPK fertilizers on growth, development and yield of tomato. Proceedings of national seminar on the production technology of tomato and chillies, Coimbatore: pp. 54-56.

11. Manjunatha, G. 2004. Effect foliar nutrition of water soluble fertilizers in bhendi (Abelmoschus esculentus) hybrid. M. Sc. (Hort.) thesis, Tamil Nadu Agricultural University, Coimbatore. 